\title{
"ANALISIS PENGARUH REPUTASI, KUALITAS PELAYANAN DAN KEPERCAYAAN TERHADAP KEPUTUSAN PEMBELIAN PADA STASIUN PENGISIAN BAHAN BAKAR UMUM (SPBU) DI KOTA SEMARANG"
}

\author{
"ANALYSIS OF REPUTATION, THE QUALITY AND RELIANCE ON PURCHASE \\ DECISION ON PUBLIC FUEL FILLING STATION (Gas Station) \\ IN SEMARANG "
}

\author{
Edy Suryawardana dan Tri Endang Yani \\ Fakultas Ekonomi Universitas Semarang
}

\begin{abstract}
In the new era, much business had done without alived gasoline fossil, far for manufakture industries. Gasoline stations was locations for stakeholder who need gasoline fossil to act their business or develop their activity on the job. Object in this research was the manufactures in the name gasoline station in Semarang city. Whit research about "Analisis Pengaruh Reputasi Perusahaan, Kualitas Pelayanan Dan Kepercayaan Terhadap Keputusan Pembelian Pada Stasiun Pengisian Bahan Bakar Umum (SPBU) Di Kota Semarang”, this research could help businessman in gasoline station to find and choose what form of the gasoline fossil effectived enought to respect the customer and it could make a strategy in order that manufactures to be a great manufacture, so the manufactures could survive and developing a strategy to entry in competing of business.

Independent variables in this research were trust $(X 1)$, firm reputation $(X 2)$ and service quality (X3) and dependent variable was buying decision ( $Y$ ). i.d. :

By result of data analisys which done from all data found, it could take some conclution

1) There was a positive and significant of regression effect from trust (X1) to buying decision ( $Y$ )

2) There was a positive and significant of regression effect from firm reputation $(X 2)$ to buying decision $(Y)$.

3) There was a positive and significant of regression effect from service quality (X3) to buying decision $(Y)$
\end{abstract}

Keywords: trust, firm reputation, service quality, buying decision.

\begin{abstract}
ABSTRAKS
Sebagian besar bisnis dunia saat ini dilaksanakan dengan tidak meninggalkan bahan bakar minyak. Terlebih lagi untuk industri manufaktur. SPBU atau Stasiun Bahan Bakar Umum merupakan tempat bagi para pihak yang membutuhkan bahan bakar untuk kegiatan bisnis ataupun menunjang aktivitasnya dalam bekerja. Objek peneliti dalam penelitian ini adalah perusahaan yang bernama Stasiun Pompa Bahan Bakar Umum atau SPBU yang ada di kota Semarang. Dengan melakukan penelitian mengenai "Analisis Pengaruh Reputasi Perusahaan, Kualitas Pelayanan Dan Kepercayaan Terhadap Keputusan Pembelian Pada Stasiun Pengisian Bahan Bakar Umum (SPBU) Di Kota Semarang", diharapkan dapat membantu para pelaku bisnis di bidang SPBU untuk memilih dan menentukan apakah bentuk kegiatan ini cukup efektif dalam mempengaruhi konsumen dan dapat menyusun strategi agar perusahaan tersebut menjadi perusahaan yang kuat, sehingga perusahaan dapat bertahan dan terus maju dalam persaingan dunia usaha yang semakin ketat. Variabel independen dalam penelitian ini adalah Kepercayaan (X1), Reputasi perusahaan (X2) dan Kualitas pelayanan (X3) sedangkan variabel terikatnya adalah keputusan pembelian (Y).
\end{abstract}


Berdasarkan hasil analisis data yang telah dilakukan terhadap seluruh data yang diperoleh, maka dapat diambil kesimpulan sebagai berikut:

1) Terdapat pengaruh positif dan signifikan dari variabel kepercayaan (X1) terhadap keputusan pembelian (Y) dapat diterima.

2) Terdapat pengaruh positif dan signifikan dari variabel reputasi perusahaan (X2) terhadap keputusan pembelian (Y) dapat diterima.

3) Terdapat pengaruh positif dan signifikan dari variabel kualitas layanan (X3) terhadap keputusan pembelian $(\mathrm{Y})$ dapat diterima.

Kata Kunci : kepercayaan, reputasi perusahaan, kualitas layanan, keputusan pembelian.

\section{Pendahuluan}

\subsection{Latar Belakang}

Sebagian besar bisnis dunia saat ini dilaksanakan dengan tidak meninggalkan bahan bakar minyak. Terlebih lagi untuk industri manufaktur. SPBU atau Stasiun Bahan Bakar Umum merupakan tempat bagi para pihak yang membutuhkan bahan bakar untuk kegiatan bisnis ataupun menunjang aktivitasnya dalam bekerja. SPBU menyediakan bahan bakar dan pelumas dari berbagai produsen dalam maupun luar negeri. Pemakaian produk SPBU yang menyebar luas mempunyai dampak dramatis pada pembeli dan pemasar (pengelola SPBU). Namun, dibalik bertambah banyaknya pembeli dan pemasar masih sedikit konsumen yang melibatkan dirinya dalam suatu transaksi jual beli di SPBU. Artinya masih banyak konsumen belum sadar dalam usaha memperoleh produk SPBU tentang resiko, reputasi dan kualitas layanan yang diterima.

Hoffman et al. (1999) menyatakan, bahwa terdapat faktor-faktor yang menyebabkan masih sedikitnya aktivitas perdagangan seperti konsumen yang tertarik pada beberapa penawaran yang ada, tidak adanya standar teknologi untuk mekanisme pembayaran yang aman dan kesenjangan keuntungan bisnis. Alasan konsumen belum bertransaksi mengenai berbagai produk SPBU adalah karena adanya kesenjangan fundamental kepercayaan yang umumnya muncul diantara banyaknya bisnis SPBU saat ini. Intinya, konsumen masih menyamaratakan resiko, reputasi dan kualitas pelayanan antara SPBU satu dengan lainnya (Wibowo, 2010).

Kepercayaan telah mendapat banyak perhatian penelitian dan telah diidentifikasi sebagai suatu kunci penggerak kesuksesan (Jarvenpaa \& Staples, 2000). Konsumen yang telah memiliki kepercayaan terhadap suatu produk/merek, akan menimbulkan minat pembelian terhadap produk/merek tersebut. Kepercayaan menurut Mayer et al. (2007) merupakan kesediaan satu pihak untuk menerima risiko dari tindakan pihak lain berdasarkan harapan bahwa pihak lain akan melakukan tindakan penting untuk pihak yang mempercayainya, terlepas dari kemampuan untuk mengawasi dan mengendalikan tindakan pihak yang dipercaya. Indikator kepercayaan terdiri dari kemampuan, niat baik dan integritas pemasar, serta emosi konsumen.

Penelitian lain mengenai keputusan pembelian tidak hanya dilakukan pada produk tetapi juga pada jasa. Beberapa faktor yang mempengaruhi kepercayaan diantaranya ada risiko dan harga. Kedua faktor ini dalam perdagangan menjadi suatu pertimbangan yang dominan bagi konsumen (Gefen et al., 2003). Risiko dianggap lebih tinggi daripada perdagangan fisik karena terbatasnya kontak fisik konsumen terhadap produk, sehingga konsumen tidak dapat melakukan pengawasan kinerja produk sebelum me- 
lakukan pembelian. Dalam perdagangan, kepercayaan berperan mengurangi masalah spesifik risiko yang mungkin ditemui oleh konsumen dalam melakukan pembelian (Luhman, 1988).

Perusahaan harus bisa menentukan strategi pemasaran yang tepat agar usahanya dapat bertahan dan tujuan utama dari perusahaan tersebut dapat tercapai. Ada beberapa faktor yang menjadi alasan suatu perusahaan bisa mendapat tempat tersendiri di hati masyarakat, misalkan bagaimana sebuah perusahaan menetapkan harga yang kompetitif, melakukan promosi yang efektif, membentuk citra dan membangun reputasi perusahaan yang baik di mata konsumen serta kualitas yang baik dan memuaskan dari produk yang mereka tawarkan kepada konsumen.

Dari data yang ada dapat disimpulkan bahwa dari tahun ke tahun konsumsi bahan bakar di Indonesia mengalami peningkatan. Ini mengindikasikan bahwa para konsumen tetap membutuhkan bahan bakar dalam mendukung kegiatan produksi atau usaha memperlancar kegiatannya/pekerjaannya walaupun dari tahun ke tahun harga bahan bakar cenderung meningkat.

Pada 17 November 2014, Presiden Joko Widodo mengumumkan kenaikan harga BBM. Premium naik dari Rp 6.500 menjadi Rp 8.500, sedangkan solar dari Rp 5.500 menjadi Rp 7.500 per liter. Menurut pemerintah, pengurangan subsidi BBM akan memberikan ruang fiskal hingga Rp 100 triliun. Menurut menteri keuangan Bambang Brodjonegoro, pemerintah akan memberikan kompensasi berpa bantuan langsung senilai Rp 200 ribu per bulan yang akan disalurkan kepada 15,5 juta keluarga. Kenaikan ini terjadi beriringan dengan turunnya harga minyak dunia secara drastis sejak Juni 2014. Pada 1 Januari 2015, Presiden Joko Widodo resmi menghapus subsidi BBM untuk jenis Premium, dan untuk bahan bakar solar ditetapkan subsidi tetap sebesar Rp 1.000. Harga BBM Premium dan Solar akan diumumkan oleh pemerintah setiap awal bulan. Perhitungan harga akan menggunakan rumus yang telah ditetapkan oleh pemerintah dan mengacu pada harga minyak dunia, kurs Rupiah terhadap Dolar AS, serta faktor inflasi. Untuk Januari 2015, harga Premium turun dari Rp 8.500 menjadi Rp 7.600, sedangkan solar dari Rp 7.500 menjadi Rp 7.250 per liter.

Perusahaan jasa seperti SPBU sering dikaitkan dengan reputasi perusahaan disamping jasa atau produknya sendiri. Zeithaml (1988) mengemukakan kualitas yang dirasakan dari suatu produk atau jasa erat hubungannya dengan reputasi yang diasosiasikan dengan nama brand tertentu, berarti memang benar adanya jika kualitas yang diterima dari sebuah produk atau jasa memang memiliki keterkaitan dengan reputasi perusahaan. Perusahaan jasa juga semakin menyadari peranan konsumen sangat penting dalam menentukan masa depan perusahaan mereka, oleh karena itu perusahaan jasa seperti SPBU harus mengetahui bahwa setiap konsumen memiliki pandangan atau persepsi yang berbeda mengenai jasa atau service yang ditawarkan

Definisi jasa atau service menurut Philip Kotler dan Gary Amstrong (2004 : 276 ) adalah aktivitas atau manfaat yang ditawarkan oleh satu pihak lain yang pada dasarnya tanpa wujud dan tidak menghasilkan kepemilikan apapun. Definisi jasa adalah suatu kegiatan yang memiliki beberapa unsur ketidakberwujudan (intangibility) yang melibatkan beberapa interaksi dengan konsumen atau properti dalam kepemilikannya dan tidak menghasilkan transfer kepemilikan. Persepsi konsumen mengenai service didefinisikan sebagai sesuatu yang khusus. Dengan memahami apa harapan dan keinginan konsumen dari suatu layanan jasa atau service maka akan didapat suatu nilai tambah tersendiri bagi perusahaan 
tersebut.

Suatu pelayanan yang diberikan secara umum dan berkala adalah bentuk pelayanan biasa yang dilakukan oleh semua kegiatan usaha kepada konsumen. Hal tersebut merupakan bentuk usaha jasa atau service yang belum lengkap, tetapi apabila jasa atau service tersebut disajikan dengan pelayanan khusus dan dengan penyajian yang berbeda atau tidak biasa dari penyajian yang pernah dilakukan oleh pelaku usaha sejenis sebelumnya, maka pelayanan tersebut membuat pelanggan atau konsumen mendapatkan sesuatu yang lebih dari yang mereka harapkan sebelumnnya. Objek peneliti dalam penelitian ini adalah perusahaan yang bernama Stasiun Pompa Bahan Bakar Umum atau SPBU yang ada di kota Semarang.

Dengan melakukan penelitian mengenai ANALISIS PENGARUH REPUTASI PERUSAHAAN, KUALITAS PELAYANAN DAN KEPERCAYAAN TERHADAP KEPUTUSAN PEMBELIAN PADA STASIUN PENGISIAN BAHAN BAKAR UMUM (SPBU) DI KOTA SEMARANG, diharapkan dapat membantu para pelaku bisnis di bidang SPBU untuk memilih dan menentukan apakah bentuk kegiatan ini cukup efektif dalam mempengaruhi konsumen dan dapat menyusun strategi agar perusahaan tersebut menjadi perusahaan yang kuat, sehingga perusahaan dapat bertahan dan terus maju dalam persaingan dunia usaha yang semakin ketat.

\subsection{Perumusan Masalah Penelitian}

Perumusan masalah yang dapat diangkat dalam penelitian ini adalah bagaimana meningkatkan penjualan bahan bakar di SPBU mengingat harga yang ditetapkan kecenderungannya mengalami kenaikan sedangkan persediaan bahan bakar yang disediakan oleh pemerintah cenderung stagnan atau menurun.

\subsection{Tujuan Penelitian}

Tujuan penelitian adalah untuk menganalisis sebagai berikut; Apakah resiko berpengaruh terhadap keputusan pembelian konsumen SPBU, Apakah kepercayaan berpengaruh terhadap keputusan pembelian konsumen SPBU, Apakah reputasi berpengaruh terhadap keputusan pembelian konsumen SPBU, Apakah kualitas pelayanan berpengaruh terhadap keputusan pembelian konsumen SPBU.

\subsection{Manfaat penelitian}

Penelitian ini bermanfaat bagi akademisi untuk lebih mendalami ilmu pengetahuan khususnya ilmu manajemen yang diterima yang berkaitan dengan reputasi, kualitas layanan, kepercayaan dan keputusan pembelian.

\section{Kajian Pustaka \\ 2.1. Kepercayaan}

Perdagangan di SPBU memeiliki keunggulan dan kelemahannya masingmasing. Salah satu kelemahan yang dimiliki dan hingga sekarang masih menjadi pertimbangan utama oleh konsumen untuk melakukan atau tidak melakukan transaksi pembelian adalah dapat dipercaya atau tidaknya suatu perusahaan. Kepercayaan yang diperoleh konsumen akan menentukan keputusan pembeliannya. Kepercayaan dibentuk oleh kemampuan, niat baik dan integritas pemasar serta emosi konsumen.

Dalam membentuk kepercayaan tersebut, terdapat pengaruh dari risiko dan harga. Risiko dalam perdagangan ditimbulkan oleh sumber, proses pengiriman, privasi, dan kesesuaian informasi. Sedangkan harga dapat diukur berdasarkan keterjangkauan harga, kesesuaian harga dengan kualitas produk, daya saing harga, dan kesesuaian harga dengan manfaat yang diberikan produk. Oleh karena itu, 


\section{H1 = Kepercayaan berpengaruh terhadap Keputusan Pembelian}

\subsection{Reputasi}

Menurut Zeithaml (1988) kualitas jasa yang dirasakan dari suatu produk atau jasa erat hubungannya dengan reputasi yang diasosiasikan dengan nama merek. Selness (1993) menyatakan bahwa dalam industri jasa dan bisnis, merek seringkali dikaitkan dengan reputasi perusahaan daripada produk atau jasa itu sendiri. Berarti kualitas yang diterima dari sebuah produk atau jasa adalah berhubungan dengan reputasi perusahaan yang digabungkan dengan nama merek produk atau jasanya.

Herbig, milewicz and Golden (1994) menyatakan bahwa reputasi perusahaan dapat dilihat dari kompetensi perusahaan tersebut dan keunggulan dibandingkan dengan kompetitornya. Adapun menurut Doney dan Cannon (1997) reputasi perusahaan berhubungan dengan sejarah atau riwayat perusahaan terutama dalam hubungannya dengan pihak lain, apakah memiliki hubungan yang lebih baik atau tidak. Reputasi perusahaan merupakan salah satu faktor yang dapat mempengaruhi keputusan pembelian konsumen terhadap suatu produk atau jasa dari suatu perusahaan. Reputasi atau merek menjadi sebuah masalah dari sikap dan kepercayaan terhadap kesadaran pada merek dan image (Maltz, 1992 : 9). Dalam penelitian terdahulu oleh Gunawan (2006) mengenai analisis faktor-faktor yang mempengaruhi keputusan nasabah menabung di PT. BRI (persero) bahwa reputasi perusahaan berpengaruh positif terhadap keputusan pembelian, serta dalam penelitian yang dilakukan $M$. Rhendria dalam penelitiannya mengenai analisis faktor yang mempengaruhi keputusan pembelian juga menyatakan bahwa reputasi perusahaan berpengaruh positif terhadap keputusan pembelian. Dari penelitian yang telah dilakukan sebelumnya dan teori yang telah dijelaskan di atas, maka dalam penelitian ini diusulkan hipotesis sebagai berikut :

\section{H2 = Reputasi mempengaruhi keputusan pembelian konsumen.}

\subsection{Kualitas Pelayanan}

Kualitas merupakan senjata perusahaan agar dapat memenangkan persaingan, namun hampir semua perusahaan terutama perusahaan yang bergerak dibidang jasa berupaya menghasilkan kualitas yang sama. Menurut Triyana ( dalam Ferdinand, 2006 ) service atau pelayanan merupakan bagian yang penting dari kegiatan pemasaran produk. Pihak konsumen menuntut pula bagaimana pelayanan purna jual dari produk yang dibelinya. Sedangkan definisi lain menurut Llosa, Chandon dan Orsingher (1998) menyatakan bahwa service quality adalah suatu instrumen yang digunakan oleh pelanggan untuk menilai pelayanan atau jasa yang diberikan oleh perusahaan.

Lima dimensi dari kualitas jasa (service quality) yang diidentifikasikan oleh Parasuraman, Zeithaml, Berry (1988) yaitu :

1. Tangibles, atau bukti fisik

2. Empathy,

3. Reliability, atau keandalan meliputi kinerja harus sesuai dengan harapan pelanggan yang berarti ketepatan waktu, pelayanan yang sama untuk semua pelanggan, sikap simpatik dan akurasi yang tinggi

4. Responsiveness, atau ketanggapan meliputi kemauan untuk membantu dan memberikan pelayananan yang cepat (responsif) dan tepat kepada pelanggan dengan informasi yang jelas.

5. Assurance, atau jaminan dan pengetahuan yaitu pengetahuan, kesopan santunan dan kemampuan para pegawai perusahaan untuk 
menumbuhkan rasa percaya para pelanggan kepada perusahaan.

Dalam penelitian yang dilakukan oleh Pradhita Widya Herfiana mengenai analisis faktor-faktor yang mempengaruhi keputusan pemilihan pasar swalayan sebagai tempat belanja juga menyatakan bahwa kualitas pelayanan berpengaruh positif terhadap keputusan pembelian. Oleh karena itu,

H3 = Semakin baik kualitas pelayanan perusahaan semakin cepat keputusan pembelian jasa.

Dari Hipotesis di atas dapat digambarkan dalam Kerangka Pikir Empiris berikut ini:

GAMBAR 2.1.

\section{KERANGKA PEMIKIRAN EMPIRIS}

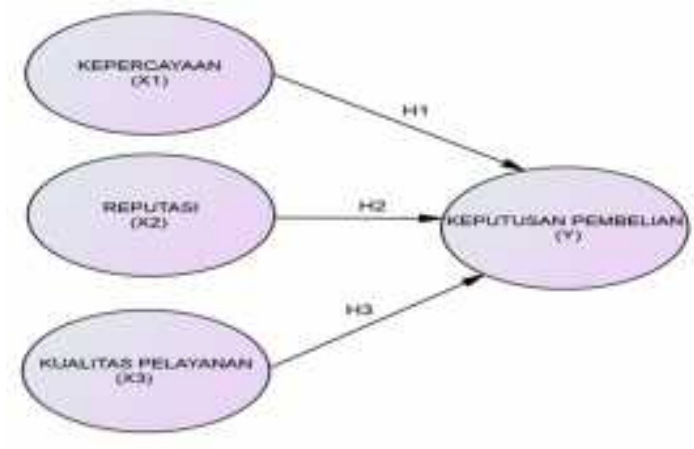

III. Metode Penelitian

3.1. Definisi Operasional

3.1.1. Variabel penelitian

Penelitian ini menggunakan dua variabel, yaitu:

1. Variabel dependen

Dalam penelitian ini yang menjadi variabel dependen adalah keputusan pembelian jasa (Y).

2. Variabel independen

Variabel independen dalam penelitian ini adalah; Kepercayaan (X1 ), Reputai perusahaan ( X2 ), Kualitas pelayanan (X3)

\subsubsection{Definisi Operasional}

a. Variabel Independen (Variabel bebas)

\section{Kepercayaan (X1)}

Kepercayaan dapat diukur dari; kepercayaan terhadap layanan petugas, kepercayaan terhadap fasilitas yang diberikan, kepercayaan terhadap perusahaan (SPBU)

\section{Variabel Reputasi perusahaan (X2)}

Indikator yang digunakan untuk variabel reputasi perusahaan adalah (Miles and Covin:2000 ) ; kredibilitas, keandalan perusahaan, nama baik

\section{Variabel Kualitas pelayanan (X3)}

Indikator yang digunakan untuk variabel kualitas pelayanan (Parasuraman, Zeithaml, Berry, 1988) adalah; Kemampuan untuk melaksanakan jasa yang dijanjikan oleh suatu perusahaan, Kemauan untuk membantu pelanggan, Pengetahuan dan kesopanan, Kepedulian terhadap konsumen, Serta penampilan fasilitas fisik.

\section{b. Variabel Dependen (Variabel} terikat )

\section{Keputusan Pembelian ( Y )}

Indikator yang digunakan untuk variabel keputusan pembelian adalah (Howard dan Shay, dalam Basu Swasta Dharmesta: 1998 ); Berfikir lama dalam memutuskan karena faktor lingkungan, Melakukan Pertimbangan dengan mengumpulkan data/informasi, Cepat Memutuskan

\subsubsection{Penentuan Populasi dan Sampel 3.1.3.1. Populasi}

Populasi dalam penelitian ini adalah seluruh konsumen SPBU di kota Semarang yang tidak bisa dihitung jumlah pastinya. Metode pengambilan sampel yang digunakan dalam penelitian ini adalah Purposive Sampling, teknik ini dipilih karena peneliti telah memahami bahwa informasi yang dibutuhkan dapat diperoleh dari satu kelompok sasaran tertentu yang mampu memberikan 
informasi yang dikendaki. Teknik ini mengedepankan beberapa kriteria sampel. Kriteria sampel dalam penelitian ini adalah konsumen yang berumur minimal 17 tahun dan membeli produk di SPBU.

Dalam penelitian ini jumlah sampel yang diambil sejumlah 97 yang diharapkan berimbang jumlah respondennya.

Jenis Data dan Sumber Data dalam penelitian ini adalah Data primer dan Data Sekunder

Metode pengumpulan data dalam penelitian ini adalah sebagai berikut; Observasi, Questioner, Wawancara dan Studi pustaka.

Metode Analisis Data dalam penelitian ini adalah Analisis Deskriptif dan analisis Kuantitatif.

\section{IV.Hasil Penelitian Dan Pembahasan}

\subsection{Analisis Data Kuantitatif}

\subsubsection{Uji Validitasi}

Berdasarkan tabel hasil uji validitas dapat diketahui bahwa semua item pertanyaan/indikator variabel Kepercayaan (X1), Reputasi Perusahaan (X2), Kualitas Layanan (X3), dan Keputusan Pembelian (Y) dinyatakan valid karena dari hasil korelasi antara hasil jawaban responden pada tiap item pertanyaan/ indikator dengan skor total di dapat hasil yang signifikan, yaitu nilai $r_{\text {hitung }}>r_{\text {tabel }}$.

\subsubsection{Uji Reliabilitas}

Hasil uji reliabilitas memperlihatkan bahwa nilai Cronbach's Alpha semua variabel di atas 0,60, sehingga dapat disimpulkan bahwa variabel kepercayaan (X1), reputasi perusahaan (X2), kualitas layanan (X3), dan keputusan pembelian (Y) dinyatakan reliabel atau dapat dipercaya/handal, yang berarti apabila data tersebut dipergunakan pada obyek penelitian yang berbeda, pada waktu yang berbeda akan memberikan hasil yang sama dengan hasil yang diperoleh pada penelitian ini.

\subsubsection{Uji Asumsi Klasik}

Uji asumsi klasik dilakukan terhadap data yang digunakan untuk analisis regresi berganda. Uji asumsi klasik terdiri dari uji normalitas, uji multikolinearitas dan uji heteroskedastisitas.

\subsubsection{Uji Normalitas}

Tabel 4.6 menunjukkan bahwa nilai $p_{\text {value }}$ (Asymp.Sig.) dari residual kedua model regresi adalah $>0,05$. Oleh karena itu dapat disimpulkan bahwa data yang digunakan dalam penelitian ini berdistribusi normal.

\subsubsection{Uji Multikolinieritas}

Berdasarkan hasil pengujian multikolinearitas model regresi menunjukkan bahwa antar variabel kepercayaan (X1), reputasi perusahaan (X2), kualitas layanan (X3), dan keputusan pembelian (Y) semuanya tidak terjadi multiko-linearitas, karena nilai tolerance masing-masing variabel independen berada di atas 0,1 dan nilai VIF masing-masing variabel independen berada di bawah 10 .

\subsubsection{Analisis Regresi Linier}

Analisis regresi linier berganda digunakan untuk melihat pengaruh variabel bebas terhadap variabel terikat. Hasil analisis regresi berganda dengan menggunakan program SPSS versi 18.0 adalah sebagai berikut:

\subsubsection{Analisis Regresi Linier Berganda}

Persamaan regresi dari tabel diatas adalah: Keputusan Pembelian= 0,278Kepercayaan +0,193Reputasi perusahaan+0,451 Kualitas layanan

Persamaan regresi tersebut mempunyai arti sebagai berikut :

1) Koefisien regresi variabel bebas (kepercayaan) bernilai positif dan signifikan terhadap variabel terikat (keputusan pembelian). Artinya, apabila variabel kepercayaan naik, 
maka variabel terikat juga meningkat dan jika variabel bebas turun, maka variabel terikat juga menurun.

2) Koefisien regresi variabel bebas (reputasi perusahaan) bernilai positif dan signifikan terhadap variabel terikat (keputusan pembelian). Artinya, apabila variabel reputasi perusahaan naik, maka variabel terikat juga meningkat dan jika variabel bebas turun, maka variabel terikat juga menurun.

3) Koefisien regresi variabel bebas (kualitas layanan) bernilai positif dan signifikan terhadap variabel terikat (keputusan pembelian). Artinya, apabila variabel kualitas layanan naik, maka variabel terikat juga meningkat dan jika variabel bebas turun, maka variabel terikat juga menurun.

\subsubsection{Pengujian Hipotesis}

Hasil Uji-t menunjukkan bahwa semua variabel bebas berpengaruh positif dan signifikan terhadap variabel terikat, karena nilai t hitung $>$ dari $\mathrm{t}$ tabel.

\subsection{Pembahasan}

\subsubsection{Pengaruh kepercayaan terhadap keputusan pembelian}

Hipotesis 1 menyatakan "kepercayaan berpengaruh positif terhadap keputusan pembelian." Hasil pengujian regresi menunjukkan $\left[p_{\text {value }}(\right.$ Sig. $\left.)=0,004\right)$ ] < 0,025 dan $\left(\mathrm{t}_{\text {hitung }}=2,301\right)>\left(\mathrm{t}_{\text {tabel }}=1,960\right)$, maka hasil uji-t adalah "signifikan" dan "positif (tanda pada t dan koefisien beta adalah positif)", sehingga Ho ditolak dan Ha diterima, yang berarti kepercayaan (X1) berpengaruh positif dan signifikan terhadap keputusan pembelian (Y) pada konsumen SPBU di kota Semarang.

"Signifikan" mengandung arti bahwa kepercayaan memang mempunyai pengaruh yang bermakna/signifikan terhadap keputusan pembelian, sehingga dapat disimpulkan bahwa perubahanperubahan yang terjadi pada keputusan pembelian, dipengaruhi/ ditentukan oleh perubahan-perubahan dari kepercayaan, tetapi tidak berlaku sebaliknya. Sedangkan hubungan "Positif" berarti bahwa perubahan-perubahan yang terjadi pada keputusan pembelian berjalan searah dengan perubahan-perubahan dari kepercayaan. Apabila variabel kepercayaan mengalami peningkatan, maka secara otomatis akan diikuti oleh peningkatan variabel keputusan pembelian, dan sebaliknya.

Koefisien beta (koefisien regresi) variabel kepercayaan adalah 0,278 atau $27,8 \%(0,278 \times 100 \%)$. Koefisien regresi ini merepresentasikan kekuatan pengaruh variabel kepercayaan terhadap variabel keputusan pembelian. Arti dari koefisien regresi $27,8 \%$ tersebut adalah: jika variabel bebas yang lain dianggap tetap (tidak ada perubahan) dan variabel kepercayaan ditingkatkan sebesar $1 \%$ daripada sebelumnya, maka akan diikuti oleh kenaikan variabel keputusan pembelian sebesar $27,8 \%$.

\subsubsection{Pengaruh reputasi perusahaan terhadap keputusan pembelian}

Hipotesis 2 menyatakan "reputasi perusahaan berpengaruh positif terhadap keputusan pembelian." Hasil pengujian regresi menunjukkan $\left[\mathrm{p}_{\text {value }}\right.$ (Sig.) = $0,001)]<0,025$ dan $\left(\mathrm{t}_{\text {hitung }}=2,632\right)>\left(\mathrm{t}_{\text {tabel }}\right.$ $=1,960)$, maka hasil uji-t adalah "signifikan" dan "positif (tanda pada t dan koefisien beta adalah positif)", sehingga Ho ditolak dan Ha diterima, yang berarti reputasi perusahaan (X2) berpengaruh positif dan signifikan terhadap keputusan pembelian (Y) pada konsumen SPBU di kota Semarang.

"Signifikan" mengandung arti bahwa reputasi perusahaan memang mempunyai pengaruh yang bermakna/signifikan terhadap keputusan pembelian, sehingga dapat disimpulkan bahwa perubahanperubahan yang terjadi pada keputusan pembelian, dipengaruhi/ ditentukan oleh 
perubahan-perubahan dari reputasi perusahaan, tetapi tidak berlaku sebaliknya. Sedangkan hubungan "Positif" berarti bahwa perubahan-perubahan yang terjadi pada keputusan pembelian berjalan searah dengan perubahan-perubahan dari reputasi perusahaan. Apabila variabel reputasi perusahaan mengalami peningkatan, maka secara otomatis akan diikuti oleh peningkatan variabel keputusan pembelian, dan sebaliknya.

Koefisien beta (koefisien regresi) variabel reputasi perusahaan adalah 0,193 atau $19,3 \%(0,193 \times 100 \%)$. Koefisien regresi ini merepresentasikan kekuatan pengaruh variabel reputasi perusahaan terhadap variabel keputusan pembelian. Arti dari koefisien regresi 19,3\% tersebut adalah: jika variabel bebas yang lain dianggap tetap (tidak ada perubahan) dan variabel reputasi perusahaan ditingkatkan sebesar $1 \%$ daripada sebelumnya, maka akan diikuti oleh kenaikan variabel keputusan pembelian sebesar 19,3\%.

\subsubsection{Pengaruh Kualitas Layanan terhadap Keputusan Pembelian}

Hipotesis 3 menyatakan "kualitas layanan berpengaruh positif terhadap keputusan pembelian." Hasil pengujian regresi menunjukkan $\left[\mathrm{p}_{\text {value }}\right.$ (Sig.) = $0,000)]<0,025$ dan $\left(\mathrm{t}_{\text {hitung }}=3,201\right)>\left(\mathrm{t}_{\text {tabel }}\right.$ $=1,960)$, maka hasil uji-t adalah "signifikan" dan "positif (tanda pada t dan koefisien beta adalah positif)", sehingga Ho ditolak dan Ha diterima, yang berarti kualitas layanan (X3) berpengaruh positif dan signifikan terhadap keputusan pembelian (Y) pada konsumen SPBU di kota Semarang. "Signifikan" mengandung arti bahwa kualitas layanan memang mempunyai pengaruh yang bermakna/signifikan terhadap keputusan pembelian, sehingga dapat disimpulkan bahwa perubahan-perubahan yang terjadi pada keputusan pembelian, dipengaruhi/ ditentukan oleh perubahan-perubahan dari kualitas layanan, tetapi tidak berlaku sebaliknya. Sedangkan hubungan "Positif" berarti bahwa perubahan-perubahan yang terjadi pada keputusan pembelian berjalan searah dengan perubahan-perubahan dari kualitas layanan. Apabila variabel kualitas layanan mengalami peningkatan, maka secara otomatis akan diikuti oleh peningkatan variabel keputusan pembelian, dan sebaliknya.

Koefisien beta (koefisien regresi) variabel kualitas layanan adalah 0,451 atau $45,1 \%(0,451 \times 100 \%)$. Koefisien regresi ini merepresentasikan kekuatan pengaruh variabel kualitas layanan terhadap variabel keputusan pembelian. Arti dari koefisien regresi $45,1 \%$ tersebut adalah: jika variabel bebas yang lain dianggap tetap (tidak ada perubahan) dan variabel kualitas layanan ditingkatkan sebesar $1 \%$ daripada sebelumnya, maka akan diikuti oleh kenaikan variabel keputusan pembelian sebesar $45,1 \%$.

\section{Simpulan}

\subsection{Simpulan}

Berdasarkan hasil analisis data yang telah dilakukan terhadap seluruh data yang diperoleh, maka dapat diambil kesimpulan sebagai berikut:

a) Terdapat pengaruh positif dan signifikan dari variabel kepercayaan (X1) terhadap keputusan pembelian (Y) dapat diterima.

b) Terdapat pengaruh positif dan signifikan dari variabel reputasi perusahaan (X2) terhadap keputusan pembelian (Y) dapat diterima.

c) Terdapat pengaruh positif dan signifikan dari variabel kualitas layanan (X3) terhadap keputusan pembelian (Y) dapat diterima.

\subsection{Implikasi Teori}

Temuan dalam pelaksanaan penelitian ini dapat ditelaah beberapa implikasi terhadap teori yang ada. Antara lain adalah : 
a. Reputasi perusahaan dapat menjadi semakin baik ataupun sebaliknya. Menurut Lau dan Lee (1999) menganggap reputasi perusahaan sebagai salah satu faktor terpenting dari karakteristik perusahaan yang dapat membentuk kepercayaan pelanggan terhadap merek. Oleh karena itu reputasi yang baik dapat diciptakan dengan meningkatkan kepercayaan konsumen terhadap perusahaan.

b. Kualitas layanan memberikan dampak yang positif terhadap setiap kegiatan yang dilakukan oleh perusahaan. Hal senada dikemukakan oleh Parasuraman, Zeithaml, dan Berry (1988) yang mendefinisikan kualitas pelayanan sebagai suatu bentuk sikap, berkaitan tetapi tidak sama dengan kepuasan, sebagai hasil dari pembandingan antara harapan dengan kinerja. Sedangkan definisi lain menurut Llosa, Chandon dan Orsingher (1998) menyatakan bahwa service quality adalah suatu instrumen yang digunakan oleh pelanggan untuk menilai pelayanan atau jasa yang diberikan oleh perusahaan.

\subsection{Implikasi Manajerial}

Berdasarkan hasil penelitian yang telah dilakukan, maka saran yang diberikan adalah :

1. Perlu ditingkatkan kepercayaan konsumen terhadap SPBU karena harga bahan bakar minyak semakin hari semakin naik diharapkan mutu produk tidak mengalami perubahan yang disebabkan oleh ulah segelintir oknum pegawai SPBU.

2. Perlu memperkuat reputasi perusahaan dengan cara menjual produk yang bermutu, stock tersedia terus menerus, tidak menimbun BBM, melatih karyawannya secara rutin dan mengedepankan kejujuran dalam pelaksanaan tugas pengisian BBM.
3. Perlu meningkatkan kualitas layanan dengan cara mempraktikkan: tersedianya BBM 24 jam, senyum ramah pegawai SPBU serta memberikan garansi jika karyawan SPBU memberikan pelayanan yang kurang maksimal kepada pelanggannya.

\subsection{Keterbatasan Penelitian}

Berdasarkan hasil penelitian yang telah dilakukan kemungkinan hasilnya kurang memuaskan disebabkan karena keterbatasan peneliti, diantaranya penelitian ini menggunakan sampel hanya dari para pelanggan di SPBU di kota Semarang. Sebaiknya dapat dikembangkan di tingkat kota atau kabupaten lainnya.

\subsection{Agenda Penelitian Yang Akan Datang}

Penelitian ini masih memungkinkan untuk dikembangkan lebih lanjut, oleh karena itu agenda penelitian mendatang diharapkan pada peneliti selanjutnya mungkin dapat mengunakan variabel yang digunakan dalam penelitian ini dengan menambah beberapa variabel atau bahkan melakukan perubahan variabel yang menurut peneliti paling mempengaruhi loyalitas pelanggan untuk menggunakan jasa SPBU pilihannya.

\section{DAFTAR PUSTAKA}

Anderson, E. W., \& Sullivan, M. W. (1999). The antecedents and consequences of customer satisfaction for firms. Mark. Sci., $12,125-143$.

Anderson, H., \& Jacobsen P. N. (2000). Creating Loyalty: Its Strategic Importance in Your Customer Strategy. In S. A. Brown (ed.), Customer Relationship Management (pp. 55-67). 
Dinawan, M, Rhendria. 2010. Analisis Faktor-Faktor yang Mempengaruhi Keputusan Pembelian (studi kasus pada konsumen yamaha mio PT harpindo jaya semarang). Tesis. Semarang: Universitas Diponegoro.

Drucker, Peter F. "Innovation And Entrepreneurship: Practice And Principle, New York:Prenential Library, 1985

Fandy Tjiptono,. 2000. Prinsip \& Dinamika Pemasaran. Edisi Pertama, Learning : Yogyakarta

Gatot Yulianto dan Purwanto Waluyo, 2004, "Pengaruh Keefektifan Komunikasi, Kualitas Teknikal, Kualitas Fungsional dan Kepercayaan Pada Komitmen Keterhubungan Bandara Ahmad Yani Semarang", Telaah Manajemen, Vol.1 Edisi 3.

Gefen, D., E. Karahanna, and D.W. Straub, "Trust and TAM in Online Shopping: An Integrated Model," MIS Quarterly, Vol. 27, No. 1:5190, 2003. Gibson, James L"Organization"New York; Business Publication, Inc, 1985.

Ghozali, Imam. 2000. Aplikasi Analisis Multivariate dengan SPSS. Semarang: Universitas Diponegoro.

-----, 2005. Aplikasi Analisis Multivariate dengan SPSS. Semarang: Universitas Diponegoro.

-----, 2006. Aplikasi Analisis Multivariate dengan SPSS. Semarang: Universitas Diponegoro.

Gunarsa Singgih D., "Psikologi Praktis : Anak, Remaja Dan Keluarga",
Jakarta, BPK Gunnung Mulia, 1991.

Gunawan (2006) Pengaruh Rasio Keuangan Terhadap Pertumbuhan Laba Pada Perusahaan Perdagangan Di Indonesia", jurnal ilmiah dan bisnis, Vol 13, No 1

Harper, Stephen C'Starting Your Own Business, New York;Mcgraw Hill, 1991

Herbig, milewicz and Golden (1994), "Differences in Forecasting Behavior between Industrial Product Firms and Consumer Product Firms,'Journal of Business \& Industrial Marketing, Volume 9, Issue 1.

Hisrich, Tobert D, Peter Michel P, "Entrepreneurship: Starting, Developing And Managing A New Enterprise, Tokyo: Richard D. Irwin, 1992

Hoffman, D.L., Novak, T.P., Peralta, M., 1999. Building consumer trust online. Communications of the ACM 42 (4), 80 - 85.

Hurlock, Elizabeth B., Psikologi Perkembangan: Suatu Pendekatan Sepanjang Rentang Kehidupan, Jakarta, Erlangga, 1991

J. P. Meyer and Allen, N. J., (1997)," Commitment in The Workplace Theory Research and Application. Califotnia: Sage Publications.

Jarvenpaa \& Staples, 2000). The use of collaborative electronic media for information sharing: an exploratory study of determinants, The Journal of Strategic Information Systems 9 (2), 129-154 
Kotler (1997) Marketing Management "Analysis, Planning, Implementation and Control" (9 th ed.). New Jersey: Prentice Hall

Lau, G. T. and Lee, S. H. (1999). "Consumers' trust in a brand and the link to brand loyalty". Journal of Market Focused Management. 4, pp. 341-370.

Llosa, Sylvie, Jean Louis Chandon And Chiara Onsingher, (1998), An Empirical Study Of Servqual 'S Dimensionality, The Service Industries Journal, Volume 18

Lupiyoadi, R Dan Hamdani, A. 2008. Manajemen Pemasaran Jasa. Salemba Empat. Jakarta. Nasir, Muhammad. 2003. Metode Penelitian. Cetakan Kelima. Jakarta: Ghalia Indonesia.

Maltz, S, A. (1992). Cookie and Cracker Technology,"AVI Publishing Company Inc. London

Miles, Morgan P \& Jeffrey G. Covin, (2000), "Environmental Marketing : A Source of Reputational, Competitive and Financial Advantage", Journal of Business Ethics, 23, p.299-311

Mollano, Diego"Corporate Responsibility And Entrepreneurship A Youth Insight" Washington:AIESEC Int, 1992

Nur Indriantoro, Dan Bambang Supomo. 2002. Metodologi Penelitian Bisnis. Yogyakata : BPFE

Pappas, James L., Mark Hirschey, Ekonomi Manajerial, Jakarta, Bina Rupa Aksara, 1995
Parasuraman, A, Valerie A Zeithml, Leonard L Berry (1985), A Conceptual Model Of Service Quality And Its Implications For Future Research, Journal Of Marketing, Volume 49.

Patty,"Pengantar Psikologi Umum", Surabaya, Usaha Nasional, 1982

Pradhita Widya Herfiana Studi Mengenai Loyalitas Pelanggan Pada Divisi Asuransi Kumpulan AJB Bumi Putera 1912 (Studi Kasus di Jawa Tengah), Jurnal Sains Pemasaran Indonesia : Vol. III, No. 3. p.289 308

Robbin Stephen P" Organization Behaviour"New Jersey; Prentice Hall Int, 1993

Selnes, Fred, 1993, "An Examination of the Effect of Product Performance on Brand Reputation, Satisfaction and Loyalty," European Journal of Marketing 27 (9), 19-35

Singarimbun, Masri, (2002), “ Manajemen Sumber Daya Manusia, " Salemba Empat, Jakarta

Sjahrir, Meramal Ekonomi Di Tengah Ketidakpastian, Jakarta, Gramedia, 1995.

Steers, Richard M, Lyman W. Porter"Motivation And Work Behaviour, Singapore:Mc Grawhill, 1991

Sugiyono. 2008. Metode Penelitian Bisnis. Cetakan Kesebelas. Alfabeta.Januari-2008.

Suharsimi Arikunto,. 2006. Prosedur Penelitian Suatu Pendekata 